\title{
The Inverted Yield Curve, The Economy, and Peaks in Interest Rates
}

\author{
Bruce Kersey \\ East Texas State University \\ Commerce, Texas
}

Periodically there are references and comments in financial and economic publications concerning the latest inversion of interest rates, which is defined as a situation where short-term interest rates are higher than long-term interest rates [1]. This is an unusual situation since long-term interest rates are normally higher because a higher rate of retum is demanded to offset the greater uncertainty and risk associated with their longer maturity.

Inversions are frequently accompanied by increasing inflationary pressures, and the Federal Reserve tightens money to combat inflation [7]. This causes a shortage in short-term money which causes short-term interest rates to rise. Long-term borrowers, such as corporations, are reluctant to borrow long-term at high rates; thus the demand for long-term funds slackens somewhat. Consequently, long-term interest rates do not rise as much as short-term interest rates. Furthermore, inverted yield curves are unusual, occurring only at about every three-to-five-year intervals.

The latest inversion in interest rates created such interest because inversions have historically preceded severe economic times [1]. This study was prepared to look at these relationships and, more specifically, to examine the timing between the inversions and certain important financial and economic events such as the economy and peaks in interest rates.

The procedures followed for this study were to determine the months when shortterm interest rates rose above long-term interest rates, the months that the economy topped-out, and the months that short-term interest rates and long-term interest rates peaked.

Short-term interest rates were measured by three-month treasury bill rates, and long-term interest rates were measured by long-term government bond rates. Because GNP is calculated only quarterly and because a more detailed calculation is desired, industrial production was used to represent the economy because it is calculated monthly.

This study covers a 20-year period from 1968 to 1989; and the first set of data that were examined appears in Table 1, which presents the findings for the beginning dates of several interest-rate inversions, peaks in industrial production, and the time lags between these two data. These data appear in columns 1,2, and 3 respectively.

By comparing columns 1 and 2 in Table 1 , it is revealed in column 3 that the inversion of interest rates preceded the crest in industrial production by an average of about twelve months, ranging from a lead time of 4 months to 17 months. Using the latest inversion beginning in early 1989 and the average lead time of 12 months, an 
average interval time indicated the economy would begin to decline in early 1990 .

\section{TABLE 1}

(1)

1st Month of

\begin{tabular}{ccc}
$\begin{array}{c}\text { 1st Month of } \\
\text { Rate Inversion }\end{array}$ & $\begin{array}{c}\text { Peak Month in } \\
\text { Industrial Production }\end{array}$ & $\begin{array}{c}\text { Lag Time in } \\
\text { Months for Ind. Prod. }\end{array}$ \\
\hline $4-68$ & $9-69$ & 17 \\
$7-73$ & $11-73$ & 4 \\
$9-78$ & $2-80^{1}$ & 17 \\
$10-80$ & $7-81$ & 9 \\
\hline
\end{tabular}

One might easily believe that when the economy begins to decline, interest rates will also decline due to less demand for money and due to a decrease in the fear of inflation, which, in turn, should decrease the inflationary premium normally added to the regular interest rate. Therefore, it would seem, that interest rates would decline simultaneously with the slow down of the economy [4].

However, upon investigation it was found that the time intervals between inversion of interest rates and interest rate tops are longer than time intervals between inversions of interest rates and peaks in the economy. This observation is bome out by comparing column 3 in Table 1 with columns 4 and 5 in Table 2 . In seven out of eight instances, the time period between the inversions of interest rates and the crests in interest rates are longer than the time periods between the inversions of interest rates and the peaks in industrial production; that is, interest rates topped-out after the economy peaked, most of the times.

Apparently, even after the economy peaks, interest rates continue to rise for several months [4]. In the case of short-term interest rates, three-month treasury bill rates continued to rise for an average of about three months (using column 3 in Table 1 and column 4 in Table 2) after the economy began to decline. In the case of longterm interest rates, long-term government bond rates continued to rise for an average of about five months (comparing column 3 in Table 1 and column 5 in Table 2) after industrial production peaked.

In addition, the latest inversion period and an average lag time of 17 months (from Table 2, column 5), can be used to determine when long-term rates may begin to decline.

A number of important caveats can be added to this study. While the data follow logical financial and economic theory and while the sequence of the events repeated

\footnotetext{
${ }^{1}$ Industrial production was slightly higher in March 1979; but there was not a substantial decline in the industrial production figure until February, 1980, so the latter figure was used as the beginning of the actual economic decline.
} 


\section{TABLE 2}

(1)

$\frac{1 \text { st Month }}{\text { of Rate }}$

Inversion

4-68

$7-73$

$9-78$

$10-80$
(2)

Peaks in Rates for:
(4)

(5)

Lags in:

3-Month Long-Term

3-Month Long-Term

Govern Bonds

T-Bills

$6-70$

21

12

$8-74$

$3-80$

$9-81$

18 Govern Bonds

26

13

18

11

repeated practically every time, it should be observed that the ranges and thus the averagesdo not allow exact tools for timing purposes. For example, the lags between the inversion of interest rates and industrial production ranged from 4 months to 17 months. Therefore, executives planning to change inventory levels or purchase new equipment need to keep this large range in mind. Likewise, governmental bodies affecting fiscal and monetary policy need to be similarly mindful of the large range.

Another caveat is that not every inversion of interest rates was immediately followed by a decline in the economy. For example, in the mid-1960's there were a couple of interest rate inversions that did not precede economic declines. However, it is believed that these exceptions do not lessen the importance of the findings from this study because during this period of time, the United States was in the Vietnam war and Johnson was spending heavily on his "Great Society" programs. The excess government spending probably kept the economy going for a short time longer. These inversions lasted, generally, only for short periods of time; and, a recession did in fact follow about 22 months later.

Another very important caveat is that the average lead time was used to roughly estimate the time of the next event. Obviously, specific events do not periodically appear time-wise equal to the "average" time lag. Each event has its own reasons for occurring: the "average" only provides a guideline.

\section{Summary}

The goal of this study was not an attempt to pinpoint exact times that each of the above events might occur because the caveats explained above would preclude such accuracy. However, this study does provide two main benefits. First, it does give rough approximations when these events might occur. Secondly, and probably more important, is that this study does reveal that there is a steady sequence of events. Planning by government and businesses can be improved by this knowledge. Thus, after a certain event takes place, decision makers at least know, with a good degree of probability, which event will occur next; and, therefore, appropriate plans can be 
inversion of interest rates was accompanied by important changes in financial and economic conditions. The patterns observed were, first the inversion of interest rates. The next event was the peak and resulting decline in the economy. The demise of the economy began, on average, about one year after the inversion of interest rates. The next occurrence was the eventual decline in short-term interest rates. The data reveal that they begin to decline, on average, about 15 months after an interest rate inversion. Finally long-term interest rates began to decline about 17 months after the inversion of interest rates.

\section{References}

1. Edgerton, Jerry and Goodman, Jordan E. "How to Steer Your Investments Around a Twisting Yield Curve." Money (February 1989), p.7.

2. Feldman, D. "The Term Structure of Interest Rates in a Partially Observable Economy." Journal of Finance (July 1989), pp. 789-812.

3. Kelly, Susan. "Strong Employment Data Help Flatten Yield Curve." American Banker (December 5, 1988), p. 5.

4. Laubacher, Harry W. "Lock in That Yield." Financial World (September 20, 1988), p. 70 .

5. Lee, B. S. "A Nonlinear Expectations Model of The Term Structure of Interest Rates With Time Varying Risk Premia." Journal of Money Credit Bank (August 1989), pp. 348-67.

6. Liebermann, Charles. "Inversion a Useful Signal." Pension \& Investment Age (January 9, 1989), p. 15.

7. Nathans, Leah J. "Why Short-Term Rates Are so Sweet; The Fed's War on Inflation Has Turned Yields Upside Down." Business Week (January 16, 1989), p. 86.

8. "Rates Throwing Curves at Trades." Futures: Magazine of Commodities andFutures (February 1989), p. 32.

9. Sharp, Eric L. "What Interest Rates Mean to Commodity Economic Cycles." Futures: Magazine of Commodities and Options (October 1989), p. 46.

10. Spares, Margaret. "Yields May Not Respond Despite Decline in Dollar." American Banker (October 17, 1988), p. 16.

11. "The Yield Curve as a Predictor of Business Cycle Turning Points." Business Economics (October 1989), p. 37. 
12. Tumovsky, S. J. "The Term Structure of Interest Rates And The Effects of Macroeconomic Policy." J. Money Credit Bank (August 1989), pp. 321-47.

13. Williams, F. "Flat Yield Curve Puts New Wood Under ARPS (Adjustable Rate Preferred Stock)." Pension Investment Age (April 1989), p. 2. 